\title{
Growth and Feeding Behaviour of the Tchanari-Barbel (Cyprinidae, Luciobarbus capito, Güldenstädt, 1773) in the Shahid Rajaei Reservoir (Sari, Iran)
}

\author{
Naderi Jolodar M. ${ }^{1,}$, Roohi A. ${ }^{1}$, Ebrahimzadeh M. ${ }^{1}$, Seyedeh Ameneh Sajjadi ${ }^{2}$ \\ ${ }^{1}$ Caspian Sea Ecology Research Center, Iranian Fisheries Science Research Institute, Agricultural Research Education and Extension \\ Organization (AREEO), Sari, Iran \\ ${ }^{2}$ Department of Agronomy, Rasht Branch, Islamic Azad University, Rasht, Iran
}

Email address:

Naderi_j@yahoo.com (Naderi J. M.), sa.sajjadi@iaurasht.ac.ir (Seyedeh A. S.)

*Corresponding author

\section{To cite this article:}

Naderi Jolodar M., Roohi A., Ebrahimzadeh M., Seyedeh Ameneh Sajjadi. Growth and Feeding Behaviour of the Tchanari-Barbel (Cyprinidae, Luciobarbus capito, Güldenstädt, 1773) in the Shahid Rajaei Reservoir (Sari, Iran). Ecology and Evolutionary Biology. Vol. 2, No. 1, 2017, pp. 14-20. doi: 10.11648/j.eeb.20170201.12

Received: January 18, 2017; Accepted: January 31, 2017; Published: March 1, 2017

\begin{abstract}
The present study, a total of 180 Luciobarbus capito was collected for growth and feeding characteristics 2016 at the Shahid Rajaei dam- Sari, Iran. Fish length to weight relationship was $w=0.0015 * \mathrm{~L}^{2.888}$ showed negative allometric growth pattern. The Bertalanfy growth equation was as $\mathrm{L}_{\mathrm{t}}=138.6\left[1^{\mathrm{e}-0.1(\mathrm{t}+0.2)}\right]$ in which $\mathrm{L}_{\infty}=138.6 \mathrm{~cm}$ and $\mathrm{k}=0.1$. Relative Length of Gut was $1.8 \pm 0.5$, which indicated the relatively herbivorous diet as a whole. Fishes ${ }^{-} 4$ years old (sub-adult) with $R L G=2.4 \pm$ 0.1 had herbivorous diet and with $\mathrm{RLG}=1.2 \pm 0.6$ tended to omnivorous behavior. The results showed that this species had not specific nutrition, and generally fed on plant and macrophyta; meat diet included fish Carassius gibelio. According to the biological characteristics of this species, there is a high potential in inland waters and due to the suitable ecological conditions for this species, it was concluded that the use of strategies to protect the species in the Caspian Sea watershed and fisheries breeding and rearing should be a priority.
\end{abstract}

Keywords: Growth, Luciobarbus capito, Shahid Rajaei Reservoir (Sari), Iran

\section{Introduction}

Tajan River is one of the main rivers of the Caspian Sea adjacent water in Mazandaran province with $120 \mathrm{~km}$ long and its basin is approximately $2000 \mathrm{~km}^{2}$. Shahid Rajaei reservoir dam was created in its pathway with Shirinrood and Sefidrood branches inlet. This river joins passes the city of Sari and enters into the Caspian Sea in Khazarabad region [17]. Cyprinidae has many genera and species, including bighead Luciobarbus capito which has economic importance [7, 14] that feeds on aquatic insects and algae such as diatoms [22]. Shahid Rajaei Dam and Tajan River fish studies have been done of very few and most research were in short time or sporadically and were on pollution, macrobenthos, fish and heavy metals $[2,4,19,14]$. In Tajan River, fishes such as Alburnoides bipunctatus were dominant with $44 \%$ and Luciobarbus brachycephalus and L. capito over one meter in length are in serious danger of extinction with both economic and protection importance [20]. L. capito has two forms in the southern Caspian Sea; one is living in the sea and immigrates into the river for reproducing, and other spends all their life cycle in freshwater. Since the destruction of upstream habitat by the dam is less safe, according to special habitat conditions created behind the dam, significant populations of $L$. capito are now present upstream of the dam $[13,15]$. Therefore, this study aimed to determine biological factors related to growth and development, such as changes in average length and weight, length-weight relationship, growth rate, sex ratio and nutritional factors related to growth and development, including length relative indices of the intestine, and feeding intensity, frequency of food and Costello [9] indicator in determining the strategy of food of 
this species in different areas of Shahid Rajaei dam and the possible effects of dams on fish biodiversity and population density.

\section{Materials and Methods}

In this study seasonal fish samples were collected at 4 stations and inlets rivers with left and right sides position of Shahid Rajaei dam area using gill nets during 2015-2016 and then were fixed in $10 \%$ formalin [5]. Ichthyology laboratory studies such as the growth parameters were conducted in the Caspian Sea Ecological Research Institute (Sari). After transferring the fish samples to the laboratory, measurement of length and weight were done by using with $1 \mathrm{~mm}$ biometrics board and digital scale of $0.01 \mathrm{~g}$. Fish sex was determined. Operculum and scales were used for age determination [16].

Bertalanfy growth equation was estimated based on .

$\mathrm{L}_{\mathrm{t}}=\mathrm{L} \infty\left\{1-\mathrm{EXP}^{[-\mathrm{K}(\mathrm{t}-\mathrm{t})]}, 0\right\}$

where $\mathrm{L}_{(\mathrm{t})}$ is length (or some other measure of size),

$\mathrm{K}$ is the growth rate and

$\mathrm{L}_{\infty}$, termed 'L infinity' in fisheries science, is the asymptotic length at which growth is zero.

Where $\mathrm{k}$ is the growth coefficient and $\mathrm{t} 0$ is the hypothetical age at which $\mathrm{L}$ (and thus $\mathrm{W}$ ) equals zero, and $\mathrm{b}$ is the exponent of the age-length relationship $\mathrm{W}=\mathrm{aL}^{\mathrm{b}}$

where W: weight of the fish in grams, L: total length in millimeters, a: constant and b: slope

To identify food consumed, each fish has been split into esophagus and gastrointestinal tract (stomach and intestines) was withdrawn. After weighing offal split, the contents were removed. For complete evacuation of contents, stomach and intestines were washed with water. After separation of the spent, contents identification was done using identification keys, and then counted by a digital scale of $0.001 \mathrm{~g} \mathrm{[5].}$

Nutritional behavior:

The following relationship was used to determine the feeding behavior of fishes [12]:

RLG= length of gut/ Total length of fish

Where RLG is Relative Length of gut

If RLG is less than 1 , the fish is carnivorous, if its value is more than 1 ; it tends to be vegetarian and tends to omnivorous in between.

GSI, Index of gut fullness was determined by Total weight of prey in stomach $\times 10,000 /$ fish weigh [20]

Costello's [9] analysis was based on a two-dimensional representation, where each point represents the frequency of occurrence and the abundance of a prey taxon (Figure 1). Costello suggested that the two diagonals of the plot represent prey importance (dominant vs rare) and predator feeding strategy (specialization vs generalized). Prey points close to $100 \%$ occurrence and $100 \%$ abundance represent the dominant prey taxa. Points clustered close to $100 \%$ occurrence and $1 \%$ abundance are considered to be indicative of a generalized diet, and points close to $1 \%$ occurrence and $100 \%$ abundance are indicative of a specialization on certain taxa by the fish $[3,9]$.

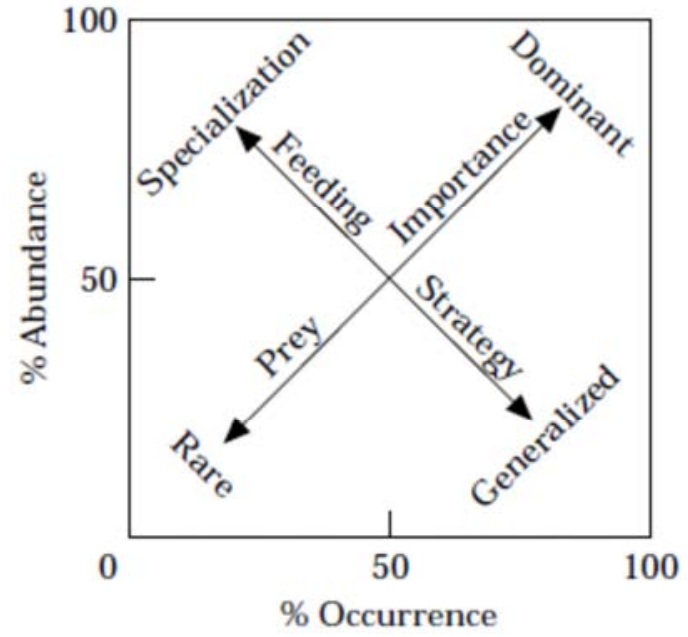

Figure 1. The explanatory diagram for the Costello [9] method.

Feeding indices

$$
\begin{gathered}
\% F=\frac{N i}{N} * 100 \\
\% P=\frac{\sum S_{i}}{\sum S t i} * 100
\end{gathered}
$$

where $\mathrm{N}$ is the total number of predators with stomach contents, $\mathrm{Ni}$ the number of predators with prey $\mathrm{i}$ in their stomach, Si the stomach content (volume, weight or number) composed by prey i, and St the total stomach content of all stomachs in the entire sample. Data analysis was performed using statistical software SYSTAT Version 9 and Excel.

\section{Results}

In our evaluation, the parameters related to the length and weight of Luciobarbus capito showed the smallest average length and weight was recorded with $14.1 \mathrm{~cm}$ and $5.02 \mathrm{~g}$, respectively, and the largest average length and weight were $85 \mathrm{~cm}$ and $5800 \mathrm{~g}$ (Table 1).

Table 1. Descriptive statistics of length and weight of Luciobarbus capito in Shahid Rajaei dam in 2016.

\begin{tabular}{lll}
\hline \multirow{2}{*}{ Sex } & Total length $(\mathbf{c m})$ & Total weight $(\mathbf{g})$ \\
\cline { 2 - 3 } & $\begin{array}{l}\text { Mean + sd deviation }(\text { min- } \\
\text { max) }\end{array}$ & $\begin{array}{l}\text { Mean + sd deviation } \\
(\text { min-max) }\end{array}$ \\
\hline Male $(\mathrm{n}=96)$ & $31.3 \pm 6.7(14-41.5)$ & $371 \pm 1690 .(50.0-660.0)$ \\
Female $(\mathrm{n}=84)$ & $48.1 \pm 18.3(18.5-85)$ & $1675 \pm 1868.3(76-5800)$ \\
Total $(\mathrm{n}=180)$ & $39.1 \pm 15.8(14-85)$ & $979.9 \pm 1435.3(50-5800)$ \\
\hline
\end{tabular}

There was a significant difference between average length and weight of male and female fish L. capito in Shahid Rajaei dam (ANOVA, $\mathrm{p}<0.05$ ). Length-weight relationship equation was $\mathrm{w}=0.015 \times \mathrm{L}^{2.888}$ the $\mathrm{b}$ value of 2.888 showed negative allometric of the fish (Table 2). Length-weight relationship equation of the male population was $\mathrm{w}=0.005 \times \mathrm{L}$ 2.225 and of female $0.016 \times \mathrm{L}^{2.883}$; the $\mathrm{b}$ Showed positive allometric growth pattern of its population in male and negative allometric growth in female (Figure 2). 
Table 2. Length-weight relationship of male and female and total population of Luciobarbus capito in Shahid Rajaei dam in 2016.

\begin{tabular}{llll}
\hline Total & Female & Male & Parameters \\
\hline $\mathbf{( n = 1 8 0 )}$ & $\mathbf{( n = 8 4 )}$ & $\mathbf{( n = 9 6 )}$ & a Mean (Min- Max) \\
\hline $0.015(0.011-0.020)$ & $0.016(0.002-0.030)$ & $0.005(0.001-0.009)$ & b Mean (Min-Max) \\
$2.888(2.831-2.944)$ & $2.883(2.680-3.086)$ & $3.225(3.021-3.428)$ & $\mathrm{R}^{2}$ \\
0.994 & 0.993 & 0.996 & A. S. E(a) \\
0.002 & 0.007 & 0.002 & A. S. E(b) \\
0.209 & 0.101 & 0.102 & \\
\hline
\end{tabular}
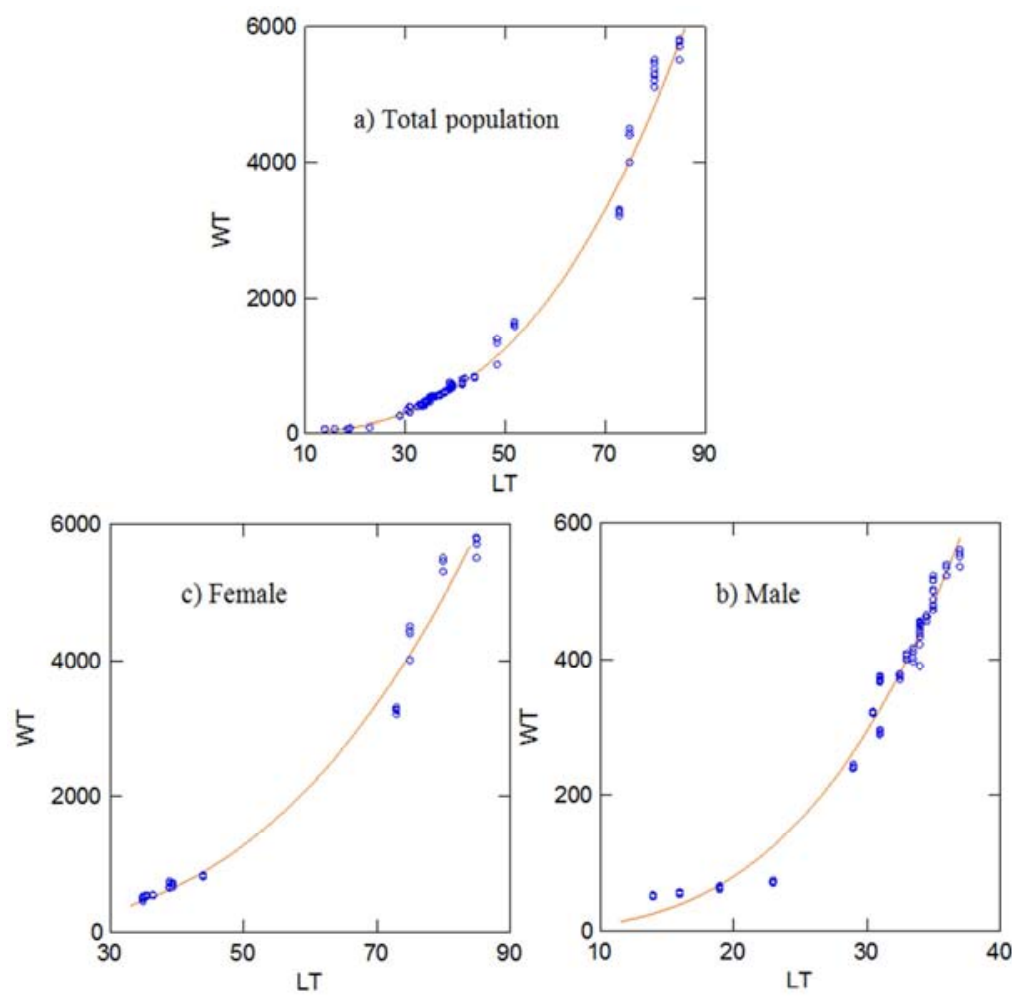

Figure 2. Growth pattern (length-weight relationship): a) total population b) Male c) Female of Luciobarbus capito in Shahid Rajaei dam in 2016.

Relative weight growth rate decreased with increasing age, and finally, the increase of age in mean weight curves tended to stabilize. With increasing the age of the fish, the growth slope curve decreased so that eventually the process of aging in length tended to stabilize. From this point on longitudinal age growth did not change with increasing age (Figure 3 ). So,
Bertalanfy growth equation of the species was $\mathrm{L}_{\mathrm{t}}=138.6[1-\mathrm{e}-$ $0.1[(\mathrm{t}+0.2)]$ that the $\mathrm{L} \infty=138.6$ and $\mathrm{k}=0.1$ (Figure 2). So the equation is known as such a growth rate of $\mathrm{k}=0.1$ predicted to be close to the maximum length. Based on the $\mathrm{k}$ growth rate was 0.1 and $t_{0}$ age of fish in zero was $0.2 \mathrm{~cm}$ and the maximum predicted length was $138.6 \mathrm{~cm}$.

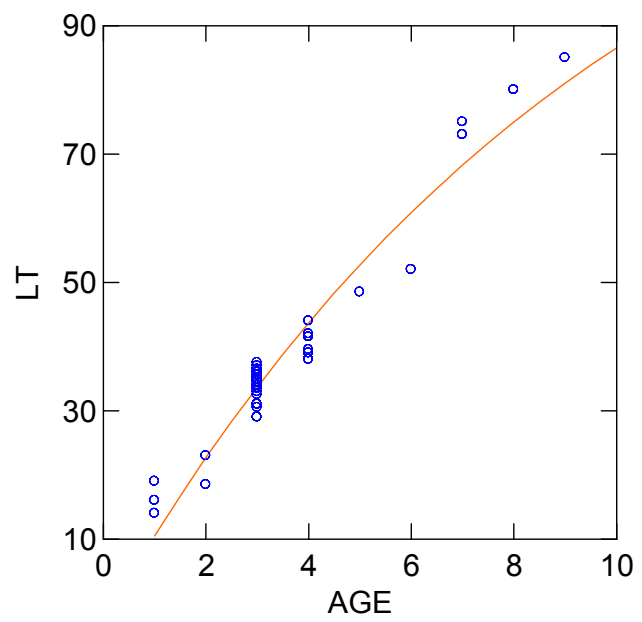

Figure 3. Mean total length (cm) as a function of age of Luciobarbus capito in Shahid Rajaei dam in 2016. 
Based on the results of the relative length of intestine (RLG) was $1.8 \pm 0.5$ that showed the diet was relatively herbivores. For age groups -4 years (before puberty) with $\mathrm{RLG}=2.4 \pm 0.1$ has herbivorous diet and after puberty with $\mathrm{RLG}=1.2 \pm 0.6$ tend toward omnivore diet. Food items available in the entire digestive tract were Oligochaeta, Macrophyta, Nematodes, Crustaceans, Carassius gibelio, Chironomidae, Coleoptera, plant, the Carassius gibelio and plant being the most abundant. The percentage frequency of food consumption was significantly different $(\mathrm{P}<0.05)$, but most of diet was belonged to Nematodes and then plant, Macrophyta and goldfish (Carassius), respectively, and others were consisted the lowest rate (Figure 4). Also, these foods were not exclusive diet because generally fed of plant and Macrophyta nutrition as Carassius that thus this species in the ecosystem of Shahid Rajaei dam had Omnivore's dietary habits. On the other hand, larger longitudinal groups are more carnivorous habits. Although in some nutritional indices in different seasons have been changes, but in total in all seasons of the diet was Omnivorous (Figure 4).
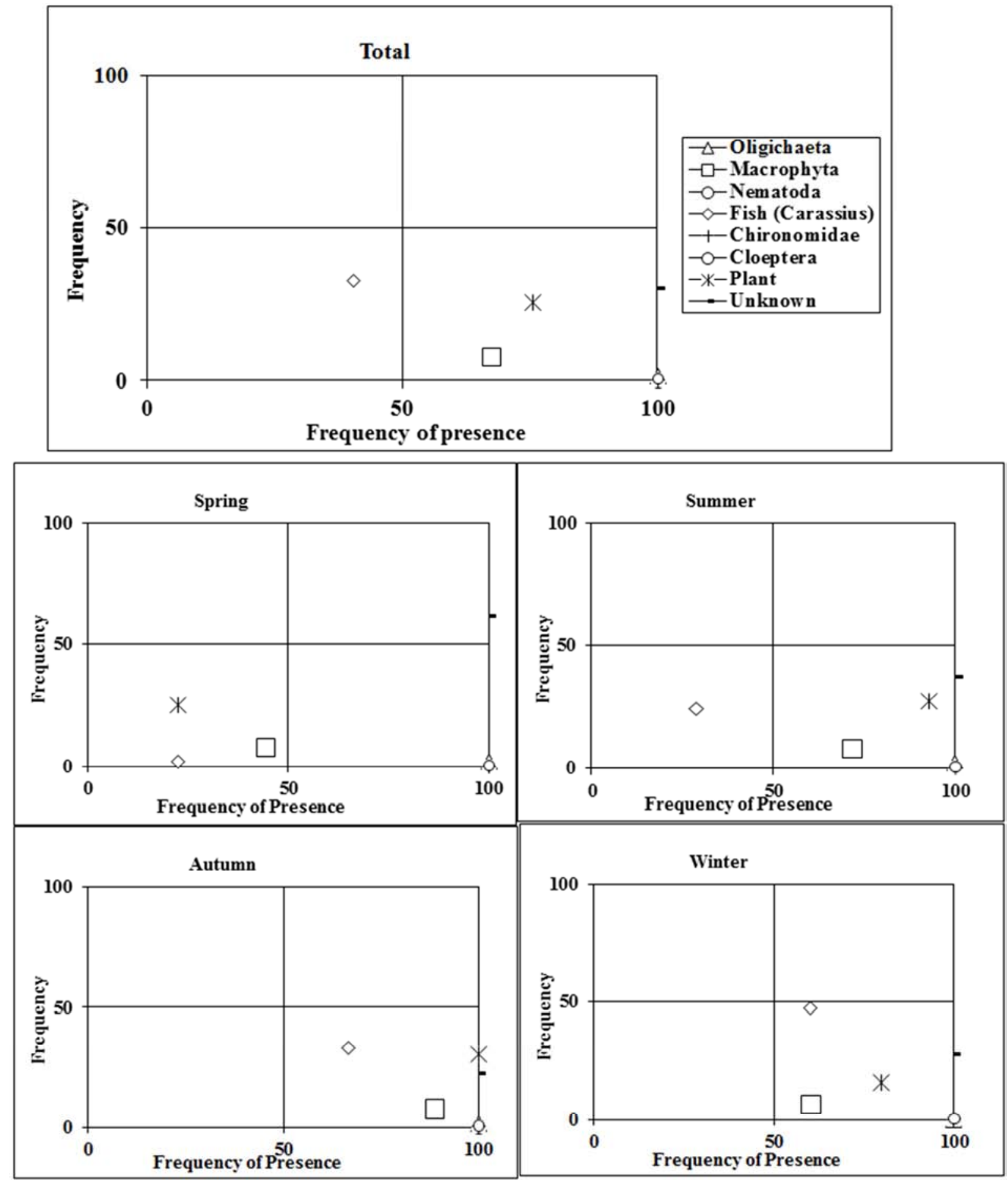

Figure 4. Interpret description of the Costello values [9] of Luciobarbus capito in Shahid Rajaei dam in 2016. 
In the study to assess the relative length of the intestine, the rate of this index decreased with increasing age and the decline in the post-maturation was slow and steady (Figure 5-A) and satiety index or feed rate, the highest was observed in the summer (after spawning time) and the lowest in winter (the coldest season of the year) (Figure 5-B).
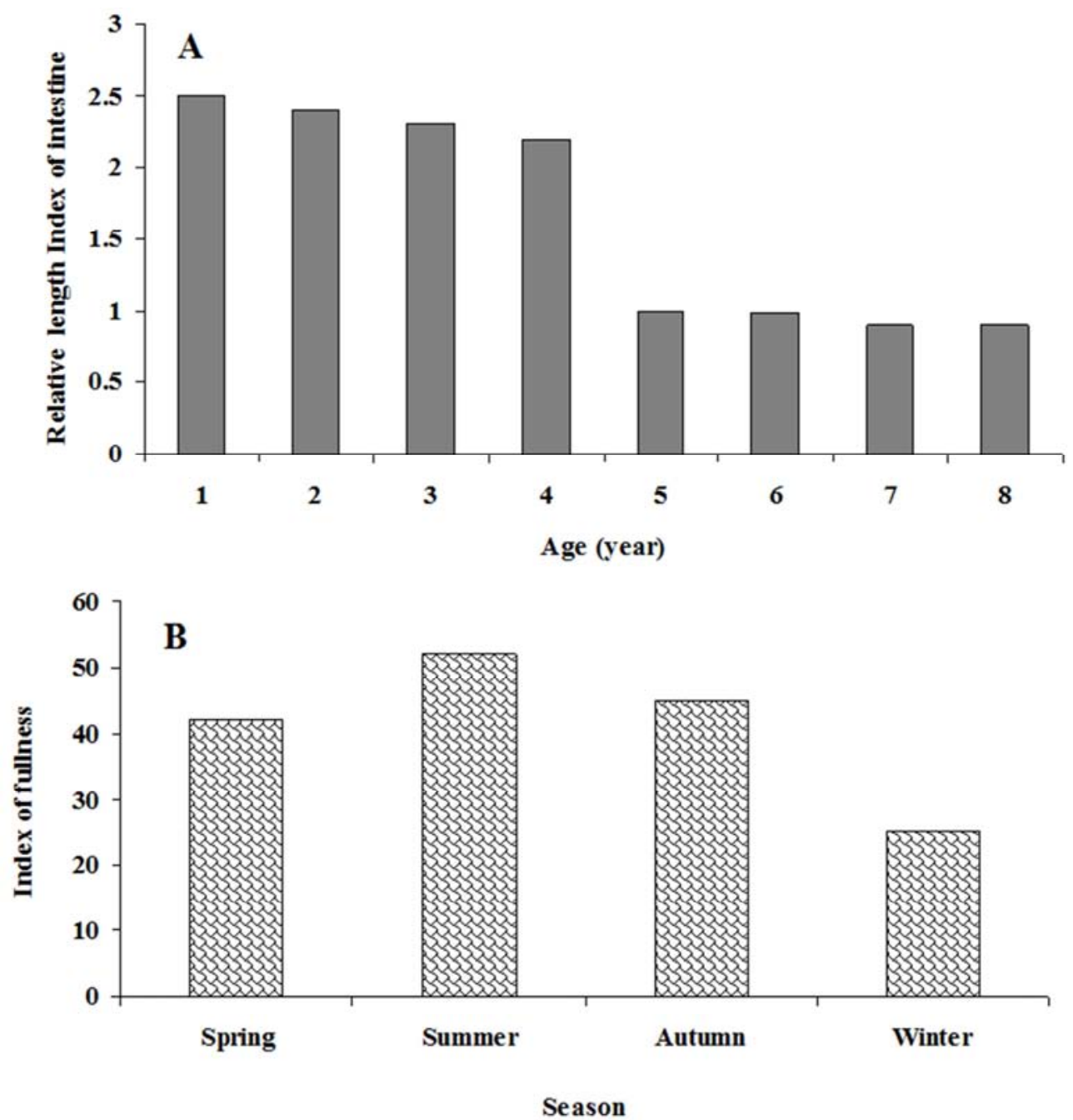

Figure 5. Changes of a) index relative length of the intestine (RLG) by age and b) the rate of feeding of Luciobarbus capito in Shahid Rajaei dam in 2016.

\section{Discussion}

Identify and evaluate ecological aquaculture, fish in the rivers and reservoirs are important issues that have not been paying enough attention to them; literature review indicates that there are very little information on most species in rivers and dams constructed $[1,8]$. In this study, the ratio of males to females was 1.14 to 1 , while on the Sardabrood river sex ratio of male to female was 7 to 1 [8]. As if the sex ratio of male to female is further stated that it is seeking to limit the fish population and on the contrary it shows that their populations are developing fish [5, 23]. Thus, it appears that the index for Luciobarbus capito in the ecosystem of Shahid Rajaei dam was more favorable than in Sardabrood River. Several studies have shown that the mean total length of fish in each age group will increase the average total length. In this study, the steepest slope of the growth observed at an early age and decreased with increasing age of the slope. The mean total weight is significantly increased with increasing age; these increases perform in time before maturation in somatic or physical. If that is near puberty and then the weight gain associated with gonadal development and sexual cells and to some extent also increase body fat. On the other hand the relation between length and weight is exponentially, it means by adding a certain amount of length, weight is added to a large amount of this value before maturity at an early age and much more. So, such changes depending on the different courses which can be related to fluctuations in supply and length-weight relationship. According to the results of this study mean total weight by age, specific pattern of weight gain and significantly with age, especially in younger fish species were observed in Luciobarbus capito in Shahid Rajaei Dam and shows length growth as well as weight growth in advanced age and finally slow and almost stop. The relationship between length and weight at age groups showed that the increase in total length, weight exponentially. In a study conducted on migratory form of the species in the Anzali region, based on the relationship 
between length and weight equation $\mathrm{a}$ and $\mathrm{b}$ values were 3.08 and 0.0078 with $\mathrm{R}^{2}=0.9954$, respectively [11]. The results of this study showed $\mathrm{a}$ and $\mathrm{b}$ values with 2.888 and 0.015 with $\mathrm{R}^{2}=0.994$ that showed the migratory form of Luciobarbus capito further growth was positive allometric. In the present study the form of this species in the Shahid Rajaei dam was negative allometric growth in female but positive allometric in male. Since the growth parameters was dependent on several factors such as population structure, properties of species and habitat conditions [18] it seems this little difference depends to their demographic characteristics, conditions of their habitats and ecosystems in the sea and the reservoir. The results of Jawad [11] showed that with the growth in the average length for this species during two consecutive years, $\mathrm{L} \infty$ with $\mathrm{k}=0.3254$ was calculated at a rate of $73.7 \mathrm{~cm}$. Tropical fish were less $L \infty$ value. For example L $\infty$ were reported $165 \mathrm{~cm}$ in Barbus esocinus [6]. The results showed that both growth rate and the total length of the infinite form of this species in the Shahid Rajaei dam are different to immigrants form. The maximum predicted total length is much more the migratory form and is closer to Barbus esocinus. It is reported that the relatively high intensity of feeding in migratory form of Luciobarbus capito was in April and May; which the reason would be attributed fish need energy to do the reproductive process. With the start of June and July (spawning time), feed rate decreased to continue after spawning. Again after the spawning process and limited energy, feed rate is added until the beginning of autumn which has relatively high rate. Although slightly reduced feed rate in September than in August, but still is more than the other months of the year. With the onset of autumn and cooling the weather feed rate is decreased and fat deposits in the body. This trend continued until the end of February and again in March readiness to increase body fat stores, increased feed rate and the cycle is repeated notes. The rate of feeding shows an increasing trend in early life has to show its maturity. After puberty, the incidence is relatively reduced and almost until the end of life with minor difference remains constant and uniform [10]. Another study in the white fish (Kutum) as well as Cyprinidae showed the same process correspond perfectly [1]. Fluctuations in nutritional Severity Index study is also quite match up with the present results.

The results showed that this species has no such specific nutrition and generally feed on Macrophyta, Plant and Carassius. Thus this species in the ecosystem of Shahid Rajaei dam had Omnivore diet habits and are more carnivorous diet group's larger longitudinal study compared to Abdoli and Naderi Jolodar [1] of a given alignment. RLG index results corresponded well with the present results. Although in some nutritional indices in different seasons have changed, but the total in all seasons of the diet Omnivore is suspected.

\section{Conclusion}

One of the important achievements of this research can be
Identify and introduction of Shahid Rajaei dam as genetic storage of this fish habitat which is in danger. At the present, a few amount of Luciobarbus capito inhabit in this reservoir and upstream rivers. In general, the results of this study showed that such a growth rate of $\mathrm{K}=0.1$ was predicted to the maximum projected growth $(\mathrm{L} \infty=138.6 \mathrm{~cm})$. Also, the length and weight of this species in the ecosystem of Shahid Rajaei dam showed tends to develop positive allometric, and in the strategy review concluded that the diet of this species in the ecosystem has no specific diet, and has Omnivore's diet. The results showed that the larger length of the fish had more carnivorous diet.

\section{References}

[1] Abdoli, A., Naderi Jolodar, M. 2008. The biodiversity of South Caspian Sea Basin fishes. Aquatic science publications. 242 pp. (in Persian).

[2] Ahmadi Mamaghani, Y., Khorasani, N., Talebi Jahromi, K. H., Hashemi, S. H., Bahador, F., 2011. Impact of agricultural activities on pesticides diazinon concentrations in Tajan River. Journal of Environmental Sciences, 8 (4), 107-117 (in Persian).

[3] Amundsen, P. A., Gabler, H. M., Staldvik, F. J. 1996. Anew approach to graphical analysis of feeding strategy from stomach contents data- modification of the Costello (1990) method. J. Fish Biol. 8: 607-614.

[4] Anvarifar, H., Farahmand, H., Nematollahi, M. A., Rahmani, H., Karami, M., Khalili, B., 2010. The effect of Shahid Rajaeii Dam on Genetic diversity and differentiation of Capoeta capoeta gracilis in Tajan River by using RAPD. Journal of Natural Environment 63 (3), 211-223 (in (Persian).

[5] Bagenal, T. 1978. Method for assessment of fish production in freshwater. T. B. P, handbook no. 3. Blackwell publication, oxford, U.K. 365 P.

[6] Barak, N. A. 1983. "Biological study of the cyprinid fish, Barbus luteus (Heckel) in Garma Marshes". Journal of Biological Sciences Research, Baghdad, 14 (2); 1983; pp. 53-70.

[7] Berg, L. S., 1949. Freshwater fishes of the U.S.S.R and adjacent countries. Israel program for scientific. translation jeruslem. Vol: 1-3.

[8] Coad, B. W., 1995. The fresh water fishes of Iran. The academy of science of the Czech Republic] Brno, $64 \mathrm{p}$

[9] Costello, M. J. (1990). Predator feeding strategy and prey importance: a new graphical analysis. Journal of Fish Biology $36,261-263$.

[10] Hoar, W. S; Randall, D. J., 1988. Fish physiology. Vol. I; 2end dition. AC. press. Newyork \& London. USA \& England; 1988.

[11] Jawad, L. A. J., 1975. "Biometric studies on three Barbus species from Basrah waters" Basrah, Iraq. The Persian Gulf Journal, University of Basrah, 3; 1975; pp. 212-247.

[12] Mookerjee, H. K. and Das, P. K. 1945. Gut of carnivorous and herbivorous fishes in relation to their food at different stages of life. Proc. Indian. Sci. Congr. 32 (3): 109. 
[13] Naderi Jelodar, M. 1999. Age, growth and feeding habits of fish Leuciscus cephalus in Tajan River, Master's thesis Free University of Tehran, $135 \mathrm{p}$.

[14] Naderi Jelodar, M. and Abdoli, A. 2004. Atlas of fishes of the southern Caspian Sea (Iranian Waters), Iranian Fisheries Journal, 112p (in Persian).

[15] Naderi Jelodar, M., Salarvand, Gh., Abdoli, A., Fazli, H., Isaaci Timuri, M., 2014. The feeding strategy of Caspian Sea kutum (Rutilus frisii kutum Kamensky, 1901), "Journal of Applied Ichthyology research, 1 (3): 63-74.

[16] Nanami, A., and Takegaki, T., 2005. Age and growth of the mudskipper Boleophthalmuspectinirostris in Ariake Bay, Kyushu, Japan. Fish Res 74: 24-34.

[17] Naseri, S. and Qaneeiyan M. 2002. Management of water quality in lakes and rivers, Tehran University Press, $120 \mathrm{p}$.

[18] Roberts, C. M. and R. F. G. Ormond. 1987. Habitat complexity and coral reef fish diversity and abundance on Red Sea fringing reefs. Marine Ecology Progress Series 41: 1-8.

[19] Saiidi, M., Karbasi, A. R., Bidhandi, G. R. and Mehrdadi, N. 2006. The effect of human activity on the accumulation of heavy metals in Tajan River in Mazandaran Province. Journal of Environmental Studies. 32 (40): 41-50.

[20] Sharghi, A., Abdoli, A., Rahmani, H., Sharaki, M., Nazari., 2011. Environmental impact assessment of Shahid Rajaei dam on aquatic fauna, Oceanography, 2 (5), 21-27 (in Persian).

[21] Shorygin, A. A., 1952. Feeding and nutritional interrelations of fish in the Caspian Sea Pishchepromizdat. Moscow. 268p.

[22] Vosoghi, Gh., and Mostajir, B., 2004. Fresh water fishes, Tehran University Press, $317 \mathrm{p}$.

[23] Whitton. B. A. 1975. River ecology, Blackwell scientific publications. Oxford, pp. X+72. 